\title{
PROFIL GAYA BELAJAR MAHASISWA PRODI PENDIDIKAN MATEMATIKA BERDASARKAN MODEL VARK
}

\author{
Martyana Prihaswati ${ }^{1}$, Eko Andy Purnomo² \\ 1,2 Pendidikan Matematika, Universitas Muhammadiyah Semarang, Indonesia \\ Email: ${ }^{1}$ martyana@unimus.ac.id
}

\begin{abstract}
Various learning style models used include Kolb Model, Fleming VAK, VARK, Honey and Mumford, Myers-Briggs Type Indicator, Gregorc, Felder-Silverman. Each learning style has different characteristics. Learning style has an important role in the learning process. Each student has his own way of absorbing the material delivered by lecturers. There are 4 student learning styles including visual, auditory, reading and kinesthetic. This research aims to find out the learning style profile of students of mathematics education programs based on the VARK model. This research is qualitative descriptive research. The research sample is a student of UNIMUS Mathematics Education program semester 2 as many as 42 students. Triangulation of data by conducting observations, questionnaires, and in-depth interviews. Based on the results of the study obtained information: (1) as many as $43 \%$ use one learning style and $57 \%$ use more than one learning style; (2) mapping the dominance of student learning as much as $67 \%$ using kinesthetic learning style, $16 \%$ reading, $12 \%$ auditory and $5 \%$ visual; (3) there are 11 learning styles consisting of a single learning style of 3, a combination of 2 learning styles as many as 3, a combination of 3 learning styles as many as 4 , and a combination of 4 learning styles as many as 1 learning style. Based on research studies it is known that students can use more than one style of learning. Based on these results, as a lecturer, students should be able to facilitate students in optimizing the use of learning styles in pursuing courses so that the results are more maximal.
\end{abstract}

Keywords: Auditory, VARK learning style, kinesthetic, reading, visual

\begin{abstract}
ABSTRAK
Berbagai model gaya belajar yang digunakan diantaranya Model Kolb, Fleming VAK, VARK, Honey dan Mumford, Indikator Tipe Myers-Briggs, Gregorc, Felder-Silverman. Setiap gaya belajar mempunyai karakteristik yang berbeda-beda. Gaya belajar memiliki peranan penting dalam proses pembelajaran. Setiap mahasiswa mempunyai cara sendiri dalam menyerap materi yang disampaikan oleh dosen. Terdapat 4 gaya belajar mahasiswa diantaranya visual, auditori, reading dan kinestetik. Penelitian ini bertujuan untuk mengetahui profil gaya belajar mahasiswa prodi Pendidikan matematika berdasarkan model VARK. Penelitian ini merupakan penelitian deskriptif kualitatif. Sampel penelitian merupakan mahasiswa prodi Pendidikan Matematika UNIMUS semester 2 sebanyak 42 mahasiswa. Triangulasi data dengan melakukan observasi, angket, dan wawancara mendalam. Berdasarkan hasil penelitian diperoleh informasi: (1) sebanyak 43\% menggunakan satu gaya belajar dan $57 \%$ menggunakan lebih dari satu gaya belajar; (2) pemetaan dominasi belajar mahasiswa sebanyak $67 \%$ menggunakan gaya belajar kinestetik, $16 \%$ reading, $12 \%$ auditori dan $5 \%$ visual; (3) terdapat 11 gaya belajar yang terdiri dari gaya belajar tunggal sebanyak 3, kombinasi 2 gaya belajar sebanyak 3, kombinasi 3 gaya belajar sebanyak 4 , dan kombinasi 4 gaya belajar sebanyak 1 gaya belajar. Berdasarkan kajian penelitian diketahui bahwa mahasiswa dapat menggunakan lebih dari satu gaya belajar. Berdasarkan hasil tersebut maka sebagai dosen harus dapat memfasilitasi mahasiswa dalam mengoptimalkan penggunaan gaya belajar dalam menempuh mata kuliah sehingga hasilnya lebih maksimal.
\end{abstract}

Kata kunci: Auditori, gaya belajar VARK, kinestetik, reading, visual

Dikirim: 26 Agustus 2021; Diterima: 16 September 2021; Dipublikasikan: 30 September 2021

Cara sitasi: Prihaswati, M., \& Purnomo, E. A. (2021). Profil gaya belajar mahasiswa prodi pendidikan matematika berdasarkan model vark. Teorema: Teori dan Riset Matematika, 6(2), $242-249$. DOI: http://dx.doi.org/10.25157/teorema.v6i2.6064 


\section{PENDAHULUAN}

Mengenal gaya belajar seseorang akan dapat menentukan cara belajar yang lebih efektif (Wahyuni, 2017). Gaya belajar mempengaruhi prestasi belajar secara signifikan (Weggelaar-Jansen et al., 2015); (Wassahua, 2016); (El-Bishouty et al., 2019); (Habibah et al., 2019); kepercayaan diri (Marković \& Jovanović, 2012), penalaran matematis (Marwiyah et al., 2020) dan meningkatkan pemahaman matematis (Azizah \& Dien, 2017). Berdasarkan pengaruh positif gaya belajar terhadap hasil belajar maka banyak pakar membuat sistem dalam mengidentifikasi gaya belajar (Seyal \& Rahman, 2015) (Prasetyo \& Iqbal, 2016); (Zhang et al., 2020) sehingga dapat memprediksi gaya belajar yang tidak pasti (Deborah et al., 2015). Strategi belajar mahasiswa telah dieksplorasi berdasarkan konteks, kreativitas (Marković \& Jovanović, 2012) teori belajar, studi empiris dan aspek pedagogis yang berinteraksi satu sama lain (Khanal et al., 2021). Strategi belajar ini nanti akan diterapkan mahasiswa yang akan menjadi kebiasaan dalam belajar dan akhirnya menjadi gaya belajar. Berdasarkan hal di atas dapat disimpulkan bahwa sangat penting sebagai seorang dosen untuk mengetahui karakteristik gaya belajar mahasiswanya. Hal ini agar dosen dapat membuat strategi belajar yang tepat berdasarkan gaya belajar mahasiswanya.

Dalam lingkungan belajar di perguruan tinggi, perbedaan individu antara mahasiswa jelas terlihat dalam hal waktu, durasi pembelajaran, konten pembelajaran yang dipilih, dan pola interaksi (Zhang et al., 2020). Berdasarkan hasil observasi pada mahasiswa prodi Pendidikan Matematika Universitas Muhammadiyah Semarang beberapa mahasiswa lebih suka menyelesaikan tugas belajar di siang hari, sementara yang lain lebih suka belajar di malam hari. Beberapa mahasiswa berpartisipasi dalam diskusi atau kegiatan kelompok, sementara yang lain lebih suka belajar sendiri. Kadang ada mahasiswa yang suka belajar menggunakan buku, menonton YouTube, dan belajar simulasi materi. Diantara semua karakteristik individu, gaya belajar merupakan teknik penting yang mempengaruhi perbedaan individu mahasiswa. Dengan kata lain, mahasiswa yang berbeda memiliki kecenderungan yang berbeda dalam hal gaya belajar. Beberapa mahasiswa dapat belajar paling baik dengan mengamati dan mendengarkan, yang lain secara visual membaca, dan ada yang dengan praktek dalam belajar (Movchun et al., 2021). Gaya belajar harus diprediksi dengan cermat (Marković \& Jovanović, 2012), karena keseimbangan psikologis peserta didik yang beragam berdasarkan pola belajar, lingkungan, waktu dan suasana hati mereka (Deborah et al., 2015). Berdasarkan hal di atas maka perlu dilakukan observasi pada mahasiswa untuk mengetahui gaya belajar mereka.

Hasil observasi awal yang dilakukan menunjukkan bahwa kemampuan mahasiswa dalam menyerap materi kurang maksimal. Hal ini terlihat dari kurang antusias mahasiswa dalam bertanya dan menjawab soal dalam perkuliahan. Selain itu nilai ujian yang diperoleh mayoritas di bawah rata-rata dari yang ditargetkan dosen. Sebelum melangkah ke strategi pembelajaran, perlu dilakukan penelusuran faktor penyebab kurang maksimalnya penyerapan materi pada mahasiswa. Berdasarkan observasi awal disimpulkan bahwa mahasiswa yang memiliki gaya belajar yang sama dengan dosen pengampu mata kuliah memiliki nilai yang lebih baik, karena dosen lebih cenderung menjelaskan materi sesuai dengan gaya belajar yang sama. Khoeron et al., (2014) menyatakan bahwa gaya belajar merupakan kombinasi seseorang dalam menyerap, mengatur, dan mengolah informasi, termasuk informasi yang diberikan saat pembelajaran berlangsung. Ketika pembelajaran disesuaikan dengan gaya belajar maka mahasiswa akan lebih mudah menyerap materi, sehingga hasil belajarpun akan lebih maksimal.

Beberapa penelitian telah dilakukan dengan tema mengidentifikasi gaya belajar diantaranya Wahyuni (2017) dengan memetakan mahasiswa pendidikan matematika Universitas Bung Hatta angkatan 2012 gaya belajar didominasi oleh Auditorial 50\%, mahasiswa angkatan 2013 didominasi oleh gaya belajar Auditorial 45\%, mahasiswa angkatan 2014 didominasi oleh gaya belajar Auditorial 50\% dan mahasiswa angkatan 2015 didominasi oleh gaya belajar Visual 50\%. Penelitian yang dilakukan di mahasiswa PGSD Universitas Esa Unggul menyimpulkan gaya belajar Visual mendominasi dengan jumlah persentase 43\%, auditorial dengan persentase 33\%, dan kinestetik dengan persentase 24\% (Syoftan, 2016). Identifikasi gaya belajar Program Studi Pendidikan Biologi Angkatan 2016 FKIP Universitas Sulawesi Barat dihasilkan $70.91 \%$ untuk gaya belajar visual, $64.17 \%$ untuk gaya belajar auditori, dan $50.19 \%$ untuk gaya belajar 
kinestetik (Rahman \& Firman, 2019). Berdasarkan hasil penelitian dapat disimpulkan bahwa setiap mahasiswa menggunakan gaya belajar yang berbeda-beda.

Penggunaan gaya belajar tidaklah tunggal, ada mahasiswa yang mengkombinasikan 3 gaya belajar, 2 atau hanya 1 gaya belajar (Zahroh, 2014). Sehingga dosen harus menciptakan lingkungan belajar yang positif, dan menggunakan metode pengajaran yang mengakomodasi berbagai gaya belajar (Bosman \& Schulze, 2018). Salah satu yang menentukan pemilihan gaya belajar adalah karakteristik mahasiswa (Sivanandan et al., 2014). Hal ini menjadi salah satu faktor yang dapat meningkatkan prestasi belajar (Zakiah, 2020). Melalui pemilihan gaya belajar yang tepat akan membuat mahasiswa lebih nyaman dalam belajar dan hasilnya akan optimal.

Pada artikel ini akan mendeskripsikan gaya belajar yang dipakai oleh mahasiswa prodi Pendidikan Matematika Universitas Muhammadiyah Semarang. Melalui pemetaan gaya belajar tersebut akan digunakan sebagai pijakan dalam membuat perencanaan pembelajaran dan media pembelajaran. Penilaian gaya belajar dapat berguna untuk tujuan refleksi pada kekuatan dan kelemahan, yang dipakai dosen dalam memainkan peran terbatas dalam pilihan model dan media pembelajaran (Barry \& Egan, 2018). Dengan dasar gaya belajar ini diharapkan mahasiswa merasa nyaman dalam proses pembelajaran sehingga memperoleh hasil belajar yang maksimal. Langkah selanjutnya membangun model gaya belajar dan mengidentifikasi gaya belajar berdasarkan pengalaman kemudian menghubungkan gaya belajar yang berbeda. Sehingga nantinya akan didapatkan suatu model yang ideal dalam gaya belajar di lingkungan perguruan tinggi. Berdasarkan hal di atas maka penelitian ini bertujuan untuk mengetahui profil gaya belajar mahasiswa prodi pendidikan matematika berdasarkan model VARK.

\section{METODE PENELITIAN}

Penelitian ini merupakan penelitian deskriptif kuantitatif. Populasi penelitian ini mahasiswa Prodi Pendidikan Universitas Muhammadiyah Semarang (UNIMUS) dengan sampel penelitian merupakan mahasiswa semester dua sebanyak 42 mahasiswa yang mengikuti mata kuliah Kalkulus Integral. Sampel diambil dengan menggunakan teknik purposive sampling, dengan pertimbangan mata kuliah Kalkulus Integral mempunyai tingkat kesulitan tinggi dan nilai yang diperoleh tidak maksimal. Penelitian ini mengunakan tiga instrumen penelitian yang meliputi (1) lembar angket penentuan gaya belajar versi Kuesioner VARK (Version 8.01). Lembar angket terdiri dari 16 pertanyaan yang dipakai untuk mengkategorikan gaya belajar visual, auditori, reading dan kinestetik; (2) jenis wawancara yang dipakai merupakan wawancara semi terstruktur. Proses wawancara menggunakan panduan wawancara yang berasal dari pengembangan topik dan mengajukan pertanyaan; dan (3) lembar observasi, indikator observasi yang digunakan adalah gaya belajar mahasiswa pada pelaksanaan perkuliahan mata kuliah Kalkulus Integral.

Metode pengambilan data dari sumber menggunakan triangulasi data dengan melakukan observasi, angket, dan wawancara semi terstruktur. Analisis data menggunakan pendekatan induktif dimana penarikan kesimpulan dari investigasi kasus yang kecil secara detail untuk memberikan gambaran besarnya (Sukestiyarno, 2020). Tahap awal pendekatan induktif dengan pengamatan awal yang diperoleh dari hasil observasi, tahap kedua mengkategorikan gaya belajar mahasiswa disajikan dalam bentuk diagram, dan tahap ketiga mengintepretasikan hasil kategori gaya belajar mahasiswa sehingga didapatkan profil gaya belajar mahasiswa.

\section{HASIL PENELITIAN}

Setiap mahasiswa mempunyai gaya belajar yang berbeda-beda. Dalam menempuh mata kuliah terdapat mahasiswa yang menggunakan satu gaya belajar yang paling dominan. Tetapi ada yang menggunakan 2, 3 bahkan terdapat 4 gaya belajar yang dipakai sekaligus. Penggunaan gaya belajar tersebut berdasarkan karakteristik mata kuliah dan kebutuhan mahasiswa. Gambaran banyaknya gaya belajar yang dipakai dapat dilihat pada Gambar 1. 

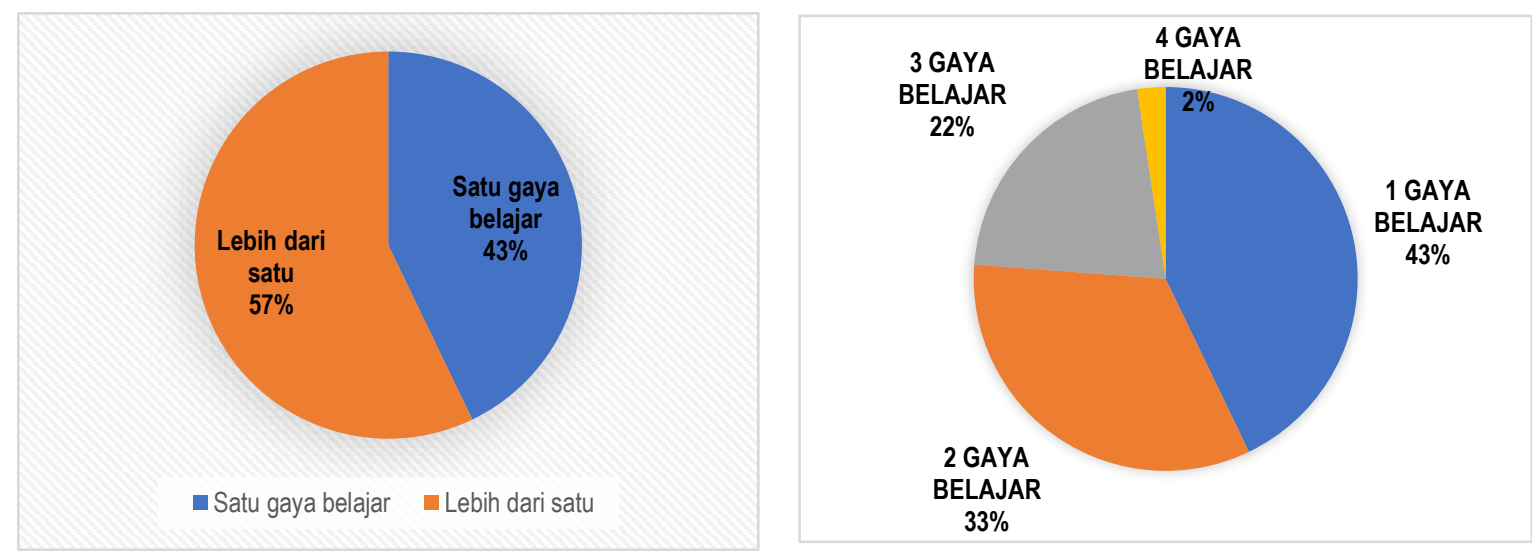

Gambar 1. Pemetaan penggunaan kategori gaya belajar 2 dan 4 gaya belajar

Berdasarkan data tersebut dapat kita simpulkan bahwa mayoritas mahasiswa menggunakan lebih dari satu gaya belajar dalam menempuh perkuliahan yaitu sebesar $57 \%$ sedangkan satu gaya belajar sebesar $43 \%$. Jika kita telusuri kembali lebih dalam yang menggunakan dua gaya belajar sebesar $33 \%$, tiga gaya belajar sebesar $22 \%$, dan empat gaya belajar sekaligus sebesar $2 \%$. Hal ini dapat ditarik kesimpulan bahwa mahasiswa menggunakan gaya belajar yang bervariasi. Ketika kita melihat satu gaya belajar yang dipakai maka gambaran dominasi gaya belajar dapat dilihat pada Gambar 2.

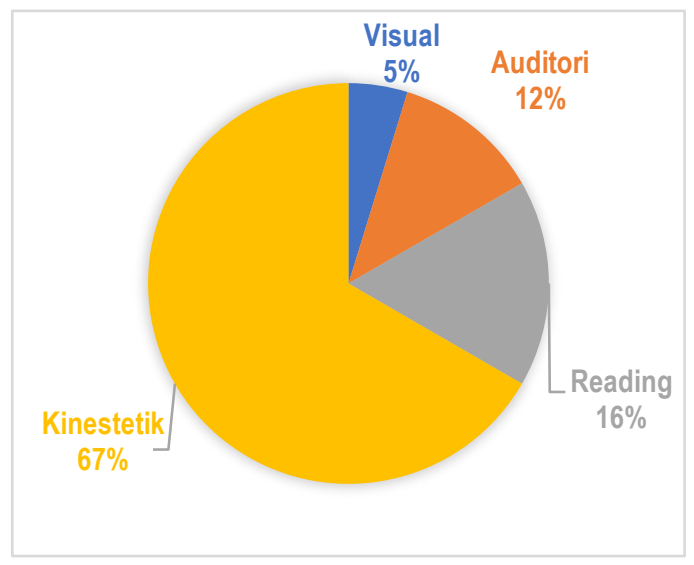

Gambar 2. Gaya belajar VARK yang paling

Berdasarkan data Gambar 2 dapat kita jabarkan bahwa mahasiswa yang menggunakan gaya belajar kinestik paling dominan yaitu $67 \%$, gaya belajar reading sebesar $16 \%$, auditori sebesar $12 \%$ dan visual sebesar $5 \%$. Ketika dikelompokkan lebih dari satu gaya belajar yang dipakai maka hasilnya dapat dilihat pada Gambar 3.

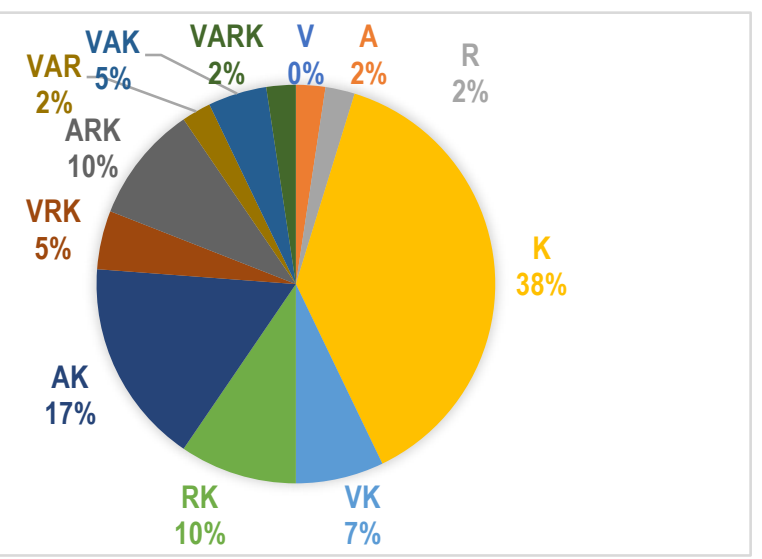

Gambar 3. Pemetaan gaya belajar mahasiswa secara keseluruhan 
Berdasarkan pemetaan gaya belajar yang digunakan dapat kita lihat terdapat 11 pengkategorian gaya belajar yang terdiri dari gaya belajar tunggal sebanyak 3 gaya belajar (Auditori, Reading, Kinestetik), kombinasi 2 gaya belajar sebanyak 3 gaya belajar (Visual Kinestetik, Reading Kinestetik, Auditori Kinestetik), kombinasi 3 gaya belajar sebanyak 4 gaya belajar (Visual Reading Kinestetik, Auditori Reading Kinestetik, Visual Auditori Reading, Visual Auditori Kinestetik), dan kombinasi 4 gaya belajar sebanyak 1 gaya belajar (Visual Auditori Reading Kinestetik). Hasil angket kemudian diperdalam dengan observasi dan wawancara mendalam. Pada observasi pelaksanaan perkuliahan, mahasiswa menggunakan gaya belajar secara bergantian Auditori, Reading, Kinestetik. Hasil wawancara mendalam terhadap perwakilan mahasiswa yang menggunakan lebih dari satu gaya belajar menunjukkan bahwa dalam penggunaan gaya belajar mahasiswa secara bergantian dalam menggunakan kombinasi gaya belajar tersebut. Observasi dilakukan sebanyak 3 kali pertemuan pada mata kuliah Kalkulus Integral. Temuan hasil observasi, dosen menggunakan cara mengajar yang menyesuaikan gaya belajar dosen sehingga siswa yang tidak memiliki gaya belajar yang sama dengan dosen, nilainya rendah. Hal tersebut dapat dilihat pada pertemuan perkuliahan. Dosen hanya menggunakan gaya belajar reading, dengan menggunakan media modul dan materi presentasi yang sebagian besar berupa narasi. Mahasiswa yang memiliki gaya belajar yang berbeda dengan dosen cenderung pasif.

\section{PEMBAHASAN}

Pemilihan gaya belajar dapat didasarkan pada budaya (Sivanandan et al., 2014), lingkungan, seperti interaksi sinkron atau asinkron (Marković \& Jovanović, 2012), kebiasaan mahasiswa, kebutuhan mahasiswa dan kondisi yang ada (Tambunan et al., 2021). Hasil penelitian dapat disimpulkan bahwa mahasiswa prodi pendidikan matematika sebagian besar menggunakan lebih dari satu gaya belajar yaitu sebesar $57 \%$ meskipun dengan kecenderungan satu gaya belajar yang dominan. Dalam pengkategorian gaya belajar, terdapat 11 kategori gaya belajar. Hal ini terjadi dikarenakan materi perkuliahan mempunyai karakteristik yang berbeda disetiap materi dan tingkat kesulitan yang tinggi. Materi pada mata kuliah ini juga mempunyai kompleksitas yang tinggi. Dengan alasan tersebut maka mahasiswa menggunakan lebih dari satu gaya belajar. Melalui kombinasi gaya belajar lebih dari satu akan meningkatkan hasil belajar (Barry \& Egan, 2018); (Zhang et al., 2020); (Papadatou-Pastou et al., 2021). Penentuan kombinasi gaya belajar setiap mahasiswa berbeda-beda. Hal ini disesuaikan dengan karakteristik mahasiswa itu sendiri.

Berdasarkan hasil penelitian, dosen direkomendasikan untuk menyediakan lingkungan belajar dengan mempertimbangkan gaya belajar dalam menentukan model dan media pembelajaran. Hal ini dikarenakan pemilihan gaya belajar yang tepat berpengaruh signifikan dalam peningkatan keterampilan kognitif (Movchun et al., 2021); kompetensi (Tambunan et al., 2021); keterampilan metakognitif dan pengaturan diri (Papadatou-Pastou et al., 2021). Kepuasan dalam pemilihan gaya belajar akan meningkatkan persepsi peserta didik yang dapat mendorong partisipasi mereka dalam proses pembelajaran (Marković \& Jovanović, 2012). Ketika mahasiswa menggunakan gaya belajar yang bervariasi, akan meningkatkan hasil belajar (Barry \& Egan, 2018); (Zhang et al., 2020); (PapadatouPastou et al., 2021).

Gaya belajar paling dominan pada mahasiswa prodi Pendidikan Matematika UNIMUS adalah gaya belajar kinestetik. Mahasiswa dengan gaya belajar kinestetik memiliki kecenderungan belajar menggunakan aktivitas fisik sehingga membutuhkan kondisi fisik yang sehat (Ula, 2013) dan menyukai pembelajaran dengan objek nyata (Mufidah, 2017). Media pembelajaran sangat dibutuhkan untuk memberi stimulus pada mahasiswa dalam memahami materi meskipun tidak lepas dari gaya belajar lain, yaitu reading, auditori, dan visual. Salah satu media pembelajaran untuk gaya belajar kinestetik adalah alat bantu peraga. Atau secara tidak langsung mahasiswa dapat menjadi media ajar dengan melakukan gerakan fisik yang disesuaikan dengan materi ajar.

Perancangan model dan media pembelajaran berdasarkan gaya belajar dapat meningkatkan kualitas dari pembelajaran. Kualitas pendidikan akan meningkat secara signifikan jika dosen memodifikasi gaya mengajar untuk mengakomodasi gaya belajar semua mahasiswa di kelas (Marković \& Jovanović, 2012). Temuan menunjukkan bahwa pembelajaran yang dirancang dengan gaya belajar tertentu dalam 
pikiran dapat meningkatkan hasil belajar (El-Bishouty et al., 2019). Gaya belajar yang telah diukur dalam penelitian ini dapat digunakan untuk menentukan metode, teknik serta strategi belajar yang cocok untuk setiap mahasiswa (Delima \& Budianingsih, 2020). Berdasarkan hal di atas maka sebagai dosen dalam merencanakan pembelajaran harus memperhatikan gaya belajar mahasiswa.

\section{KESIMPULAN}

Berdasarkan hasil penelitian dapat disimpulkan bahwa (1) sebanyak $43 \%$ menggunakan satu gaya belajar dan $57 \%$ menggunakan lebih dari satu gaya belajar; (2) pemetaan dominasi belajar mahasiswa sebanyak $67 \%$ menggunakan gaya belajar kinestetik, sebanyak $16 \%$ menggunakan reading, sebanyak $12 \%$ menggunakan auditori, dan sebanyak $5 \%$ menggunakan visual; dan (3) terdapat 11 kategori gaya belajar yang terdiri dari gaya belajar tunggal ada 3 , kombinasi 2 gaya belajar ada 3 , kombinasi 3 gaya belajar ada 4, dan kombinasi 4 gaya belajar ada 1.

\section{REKOMENDASI}

Berdasarkan hasil kesimpulan penelitian, rekomendasi peneliti yaitu (1) dosen disarankan menyusun media pembelajaran yang sesuai gaya belajar mahasiswa sebagai stimulus dan sarana penunjang dalam memahami materi; dan (2) dosen diharapkan menggunakan lebih dari satu model gaya pembelajaran agar hasil pembelajaran lebih optimal.

\section{UCAPAN TERIMA KASIH}

Peneliti mengucapkan terima kasih sebesar-besarnya atas dukungan dan kontribusinya kepada: (1) DRPM Kemenristek atas pendanaan Penelitian Desentralisasi dalam Penelitian Terapan Unggulan Perguruan Tinggi; dan (2) Venissa Dian Mawarsari, M.Pd, selaku Ketua Program Studi Pendidikan Matematika Universitas Muhammadiyah Semarang yang telah memberikan dukungan dan perijinan untuk melaksanakan penelitian.

\section{DAFTAR PUSTAKA}

Azizah, F., \& Dien, C. A. (2017). Meningkatkan kemampuan pemahaman matematis melalui model pembelajaran visual auditory kinestetic (vak). Seminar Matematika dan Pendidikan Matematika UNY.

Barry, M., \& Egan, A. (2018). An adult learner's learning style should inform but not limit educational choices. International Review of Education, 64(1), 31-42. https://doi.org/10.1007/s11159-0179694-6.

Bosman, A., \& Schulze, S. (2018). Learning style preferences and mathematics achievement of secondary school learners. South African Journal of Education, 38(1), 1-8. https://doi.org/10.15700/saje.v38n1a1440.

Deborah, L. J. E. G. A. T. H. A., Sathiyaseelan, R., Audithan, S., \& Vijayakumar, P. (2015). Fuzzylogic-based learning style prediction in e-learning using web interface information. SadhanaAcademy Proceedings in Engineering Sciences, 40(2), 379-394. https://doi.org/10.1007/s12046-015-0334-1.

Delima, N., \& Budianingsih, Y. (2020). Gaya belajar dan mathematics self-concept terhadap minat akademik mahasiswa. Teorema: Teori dan Riset Matematika, 5(1), 1. https://doi.org/10.25157/teorema.v5i1.3296.

El-Bishouty, M. M., Aldraiweesh, A., Alturki, U., Tortorella, R., Yang, J., Chang, T. W., Graf, S., \& Kinshuk. (2019). Use of felder and silverman learning style model for online course design. 
Educational Technology Research and Development, 67(1), 161-177. https://doi.org/10.1007/s11423-018-9634-6.

Habibah, N., Rahmawati, S., \& Sayekti, A. (2019). Pengaruh gaya belajar terhadap prestasi mahasiswa generasi z di perguruan tinggi. Perspektif Ilmu Pendidikan, 33(2), 7-18. https://doi.org/10.21009/pip.332.2.

Khanal, B., Panthi, R. K., Kshetree, M. P., Acharya, B. R., \& Belbase, S. (2021). Mathematics learning strategies of high school students in Nepal. SN Social Sciences, 1(7), 1-28. https://doi.org/10.1007/s43545-021-00165-y

Khoeron, I. R., Sumarna, N., \& Permana, T. (2014). Pengaruh gaya belajar terhadap prestasi belajar peserta didik pada mata pelajaran produktif. Journal of Mechanical Engineering Education, 1(2), 291. https://doi.org/10.17509/jmee.v1i2.3816

Marković, S., \& Jovanović, N. (2012). Learning style as a factor which affects the quality of e-learning. Artificial Intelligence Review, 38(4), 303-312. https://doi.org/10.1007/s10462-011-9253-7.

Marwiyah, S., Pujiastuti, H., \& Sukirwan, S. (2020). Profil kemampuan penalaran matematis siswa ditinjau dari gaya belajar v-a-k pada materi bangun ruang sisi datar. Teorema: Teori dan Riset Matematika, 5(2), 295. https://doi.org/10.25157/teorema.v5i2.3738.

Movchun, V., Lushkov, R., \& Pronkin, N. (2021). Prediction of individual learning style in e-learning systems: opportunities and limitations in dental education. Education and Information Technologies, 26(3), 2523-2537. https://doi.org/10.1007/s10639-020-10372-4.

Papadatou-Pastou, M., Touloumakos, A. K., Koutouveli, C., \& Barrable, A. (2021). The learning styles neuromyth: when the same term means different things to different teachers. European Journal of Psychology of Education, 36(2), 511-531. https://doi.org/10.1007/s10212-020-00485-2.

Prasetyo, T. F., \& lqbal, M. (2016). Sistem pakar identifikasi gaya belajar mahasiswa berbasis web. Seminar Nasional Sains dan Teknologi 2016 Fakultas Teknik Universitas Muhammadiyah Jakarta, November, 1-7. https://jurnal.umj.ac.id/index.php/semnastek/article/view/776.

Rahman, S. R., \& Firman. (2019). Identifikasi gaya belajar mahasiswa pendidikan biologi universitas sulawesi barat. Jambura Edu Biosfer Journal, 1(1), 1. https://doi.org/10.34312/jebj.v1i1.2040.

Seyal, A. H., \& Rahman, M. N. A. (2015). Understanding learning styles, attitudes and intentions in using e-learning system: evidence from brunei. World Journal of Education, 5(3), 61-72. https://doi.org/10.5430/wje.v5n3p61.

Sivanandan, P., Letchumanan, T., Ramayah, M., \& Nasrijal, N. H. (2014). Learning style preferences: influence of cultural background among business students. Internationl Journal of Arts and Commerce, 3(5), 87-98.

Sukestiyarno, Y. L. (2020). Metode penelitian pendidikan (2nd ed.). Unnes Press.

Syoftan, H. (2016). Identifikasi gaya belajar mahasiswa prodi pendidikan guru sekolah dasar universitas esa unggul. Eduscience, 1(2), 70-79. 
Tambunan, H., Silitonga, M., \& Sidabutar, U. B. (2021). Online and face-to-face composition in forming the professional competencies of technical teacher candidates with various learning style types. Education and Information Technologies, 26(2), 2017-2031. https://doi.org/10.1007/s10639020-10349-3.

Wahyuni, Y. (2017). Identifikasi gaya belajar (visual, auditorial) universitas bung hatta. Jppm, 10(2), 128-132.

Wassahua, S. (2016). Analisis gaya belajar siswa terhadap hasil belajar matematika pada materi himpunan siswa kelas vii smp negeri karang jaya kecamatan namlea kabupaten buru. Jurnal Matematika dan Pembelajarannya, 2(1), 84-104.

Weggelaar-Jansen, A. M., Van Wijngaarden, J., \& Slaghuis, S. S. (2015). Do quality improvement collaboratives' educational components match the dominant learning style preferences of the participants? Quality, performance, safety and outcomes. BMC Health Services Research, 15(1), 1-13. https://doi.org/10.1186/s12913-015-0915-z

Zahroh. (2014). Kecenderungan gaya belajar mahasiswa dalam menyelesaikan masalah fungsi bijektif. Jurnal Kebijakan dan Pengembangan Pendidikan, 2(1), 72-81.

Zhang, H., Huang, T., Liu, S., Yin, H., Li, J., Yang, H., \& Xia, Y. (2020). A learning style classification approach based on deep belief network for large-scale online education. Journal of Cloud Computing, 9(1). https://doi.org/10.1186/s13677-020-00165-y.

Zakiah, N. E. (2020). Level kemampuan metakognitif siswa dalam pembelajaran matematika berdasarkan gaya kognitif. Jurnal Riset Pendidikan Matematika, 7(2), 132-147. doi: https://doi.org/10.21831/jrpm.v7i2.30458 